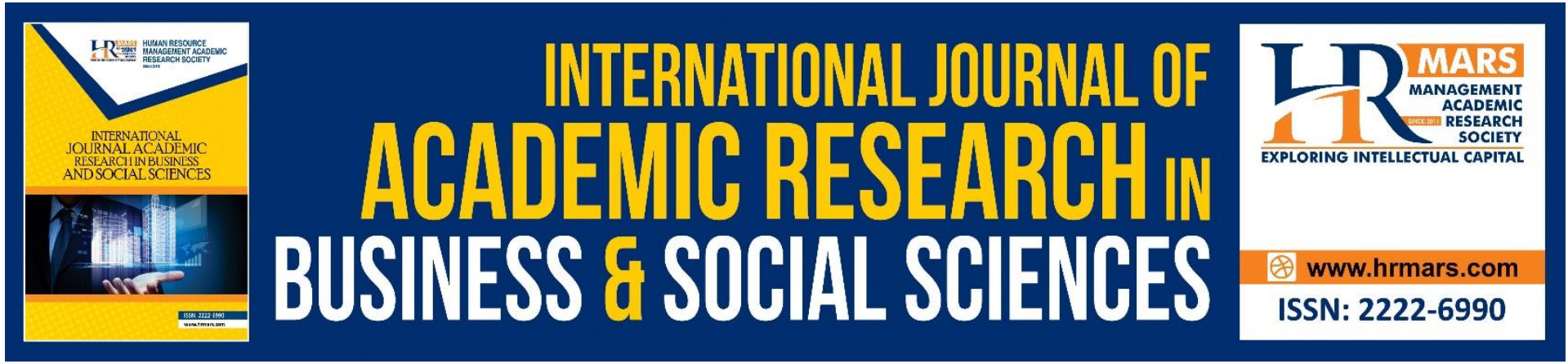

\title{
Comparative Study: Factors that Influence Entrepreneur Intention Between B40 and M40
}

Norazman Harun, Noorizda Emellia Mohd Aziz, Nor Halawah Ahmad, Surya Binti Ahmad Royali, Masliana Binti Tamrin \& llya Yasnorizar Binti llyas

To Link this Article: http://dx.doi.org/10.6007/IJARBSS/v11-i9/10725

DOI:10.6007/IJARBSS/v11-i9/10725

Received: 05 July 2021, Revised: 27 July 2021, Accepted: 24 August 2021

Published Online: 12 September 2021

In-Text Citation: (Harun et al., 2021)

To Cite this Article: Harun, N., Aziz, N. E. M., Ahmad, N. H., Royali, S. B. A., Tamrin, M. B., \& Ilyas, I. Y. B. (2021). Comparative Study: Factors that Influence Entrepreneur Intention Between B40 and M40. International Journal of Academic Research in Business and Social Sciences, 11(9), 310-320.

Copyright: @ 2021 The Author(s)

Published by Human Resource Management Academic Research Society (www.hrmars.com)

This article is published under the Creative Commons Attribution (CC BY 4.0) license. Anyone may reproduce, distribute, translate and create derivative works of this article (for both commercial and non-commercial purposes), subject to full attribution to the original publication and authors. The full terms of this license may be seen at: http://creativecommons.org/licences/by/4.0/legalcode

Vol. 11, No. 9, 2021, Pg. 310 - 320

Full Terms \& Conditions of access and use can be found at http://hrmars.com/index.php/pages/detail/publication-ethics 


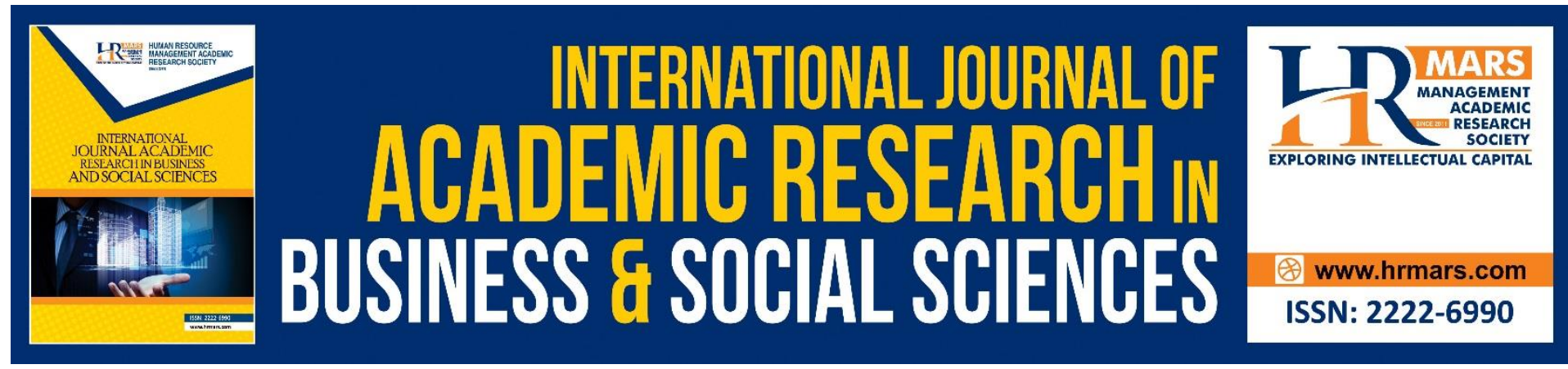

\title{
Comparative Study: Factors that Influence Entrepreneur Intention Between B40 and M40
}

\author{
${ }^{1}$ Norazman Harun, ${ }^{2}$ Noorizda Emellia Mohd Aziz, ${ }^{3}$ Nor Halawah \\ Ahmad, ${ }^{4}$ Surya Binti Ahmad Royali, ${ }^{5}$ Masliana Binti Tamrin, \& \\ 6llya Yasnorizar Binti llyas \\ 1, 3, \& \& ${ }^{5}$ Faculty of Business and Management, UiTM Melaka Branch, ${ }^{2}$ Faculty of Business \\ Innovation \& Technology, KUIM, ${ }^{6}$ Faculty of Communication and Media Studies, UiTM \\ Melaka Branch, Malaysia
}

\begin{abstract}
The main objective of this study is to compare factors that effecting entrepreneur intention of higher Education Institute (HEI) students between B40 family with M40 and T20 family in Melaka. Factors such as initiative, seek on opportunities, act on opportunities, information seeking, concern for high quality of work, commitment to work contract, efficiency orientation, systematic planning, problem solving, self-confidence and assertiveness are tested the correlation with entrepreneur intention. A total of 475 respondents were collected to give their response, where 316 respondents came from B40 family and 159 respondents from M40 and T20 family around HEI in Melaka. Data collection method using structured questionnaire and deliver to respondents by google form apps. The comparative study includes the level of entrepreneur intention for both groups. Hypotheses testing of factors toward entrepreneur intention for both group also tested. At the end, researcher seek comparative analysis the dominant factor that effecting entrepreneur intention among students for both groups. The research finding show that the level of entrepreneur intention among students from M40 and T20 family is higher than students from B40 family. Finding also state that all factors have positive significant relationship with entrepreneur intention for both group but in different situation. Two factors are most dominant factor toward entrepreneur intention for student from M40 and T20. While for students from B40, there are four factors most dominant toward entrepreneur intention. As conclusion, the university can focus to certain factors for both groups of student to improve entrepreneur intention among them.
\end{abstract}

Keywords: Entrepreneur Intention

\section{Introduction}

Entrepreneurship is an innovative and creative process that has the potential to add value to products, create jobs, increase productivity, diversify markets, improve social well-being, and grow the economy more broadly (Guerrero, Rialp, \& Urbano, 2008). Here, according to Sharifi et al., 2013) this is felt to be particularly important for developing countries where there are more resource constraints to enrich and diversify products and experiences. To ensure that 
the country continues to have a supply of entrepreneurs then a variety of studies related to entrepreneurial intentions should be conducted by researchers among academics and entrepreneurs to find out how the initial intentions of entrepreneurs in the early stages can potentially be a factor in influencing entrepreneurship (Kourosh, 2019). The entrepreneurial intentions of students at Higher Education Institutions (HEIs) have been studied and researched from different perspectives for a many years ago, but still lack of comparison research (Hou et al., 2019). In addition, an individual's interest in entrepreneurial activities is a strong positive feeling to increase an individual's entrepreneurial confidence. Therefore, the comparative study of entrepreneurial intentions is expected to stimulate the entrepreneurial intentions of university students in maintaining the positive emotions of entrepreneurs about entrepreneurial activities and make entrepreneurs clarify their identity as entrepreneurs. Especially when they know their own competencies more transparently. This can certainly provide an increase in entrepreneurial intention in HEls students. The study by Hou et al. (2019) showed that students in entrepreneurship majors have higher entrepreneurial intentions than students in non-entrepreneurship majors, and these students tend to create new businesses after graduation.

According to previous studies, it is generally believed that entrepreneurship competencies has a positive impact on entrepreneurial intention (Rideout and Gray, 2013). In addition, a number of management courses positively related to the entrepreneurial intentions of university students (Chen et al., 1998) are widely developed in HEls. By acquiring entrepreneurial knowledge, increasing entrepreneurial awareness, and enhancing students 'entrepreneurial abilities and understanding of the entrepreneurial spirit. Thus, entrepreneurial competencies are easily formed to enhance the entrepreneurial intentions of HEls students. Additionally, Bird (1995) referring from McLelland and McBer (1985) stated that entrepreneurship need to understand entrepreneurial competencies. Entrepreneurial competencies are the behaviours and skills that are learned through effective training and education rather than inherited (Azevedo et al., 2012). There are 13 types of entrepreneurial competencies such are the initiative, sees and acts opportunities, persistence, information seeking, concern for high quality of work, commitment to work contract, efficiencyorientation, systematic planning, problem solving, self-confidence, assertiveness, persuasion, and use of influence strategy. Dosm (2021) mentioned that in 2020, the world has been hit by the unprecedented event of Covid-19, causing the worst economic downturn in Malaysia since the last declined in 1998. The implementation of various Movement Control Order (MCO) to contain the spread of Covid-19 has led to the increase in the number of job losses and subsequently rise in the country's number of unemployment by 200 thousand to record 718.1 thousands persons in 2020. New entrants to the labour markets especially fresh graduates are no exception, affected by the pandemic. Competition of getting jobs among the graduates are getting more challenging with the presence of more unemployed persons who lost their jobs during the pandemic. Because of that issues households income also affected and affect members in the family to jointly seek side income. Most of them, directly act as an entrepreneur in order to get fast cash money through selling products or services. Its very important to understand the comparison of entrepreneurs intention for different households income which categorized as B40, M40 and T20. So, this research focused on Comparative Study about Factors That Influence Entrepreneur Intention Between B40 And M40 family income among HEls students in Melaka. All factors that influence entrepreneur intention identified from Personal Entrepreneurial Competencies (PECs). Its important to do a 
comparison to find is there have different level of Entrepreneur Intention of HEI student between B40 and M40/ T20 family income, to know the relationship between all factors and entrepreneur intention of $\mathrm{HEl}$ student between $\mathrm{B} 40$ and M40/ T20, also the dominant factors and the results will give alternatives to improve Entrepreneur Intention of HEl student between B40 and M40/ T20 family income in Melaka.

Thus, this research has come up with forth (4) main objectives:

- To determine the level of Entrepreneur Intention of HEl student between B40 and M40/ T20 family in Melaka.

- To evaluate the relationship between All Factors and Entrepreneur Intention of HEI student between B40 and M40/ T20 family in Melaka

- To determine the most dominant factor that influence Entrepreneur Intention of $\mathrm{HEI}$ student between B40 and M40/ T20 family in Melaka

- To determine the alternative to improve Entrepreneur Intention of HEl student between B40 and M40/ T20 family in Melaka

\section{Problem Statement}

Nowadays, with the emergence of entrepreneurial activities and entrepreneurial incubators, more and more people are focusing on entrepreneurial studies. Continuation of that, university students are often considered as potential entrepreneurs, entrepreneurial intention is a core variable to predict the entrepreneurial behavior of university students. According to Hou et al (2019) although there have been many studies related to entrepreneurial intention among students in HEls, but the results still can not be combined with mechanisms and outcomes related to how entrepreneurial intention can be influenced by different factors. Thus, he stressed that there is still a lack of research and comparative studies for that matters. According to Dosm (2021), the statistic for unempoyed from the viewpoint of unemployment duration, over than 70 per cent of unemployed graduates were in active unemployment comprised of 158.4 thousand persons. Other than that, out of this total, graduates who were unemployed less than three months recorded the highest share of 45.1 per cent ( 71.4 thousand persons). Meanwhile, 30.1 per cent ( 47.6 thousand persons) and 14.8 per cent ( 23.5 thousand persons) of them were unemployed within three to five months and six to twelve months. Also, graduates who were in long term unemployment or more than a year encompassed of 10.1 per cent or 16.0 thousand persons. It can be concluded that from the overall total of unemployed graduates, inactively unemployed graduates who were not seeking for jobs accounted for 21.7 per cent or 44.0 thousand persons in 2020 . According to Astro (2021) the Covid-19 pandemic has had a significant impact on household income and made more people poorer, according to a study conducted by the Department of Statistics. The Covid-19 impact study on household income in Malaysia for 2020 revealed that the number of poor households increased to 639,800 in 2020, up from 405,400 in 2019. The findings of the study are contained in the Household Income Estimates and Incidence of Poverty Report, Malaysia, 2020 which the department released today. Also, according to Chief Statistician Datuk Seri Dr Mohd Uzir Mahidin said in a statement that the incidence of absolute poverty also increased, from 5.6 per cent in 2019 to 8.4 per cent in 2020, and that the incidence of hardcore poverty is estimated to increase from 0.4 per cent (2019) involving 27,200 households to 1.0 per cent involving 78,000 households. He said the pandemic had also affected the structure of household groups, with 20 per cent of households from the M40 group with income between RM4,850 and RM10,959 having moved to the B40 group. 
Households in the T20 group were also affected by the Covid-19 pandemic where 12.8 per cent of this group has shifted to the M40 group. Then, the percentage decrease in income for B40 and M40 households was larger than the T20 households group, the income distribution for B40 and M40 declined to 15.9 per cent (2019: 16.0 per cent) and 36.9 per cent (2019: 37.2 per cent), respectively. Meanwhile, the T20 group owned 47.2 per cent of income increased by 0.4 percentage points from 2019. Other than that, the mean of monthly household gross income decreased by negative 10.3 per cent to record RM7,089 as compared to RM7,901 in 2019 and added that the decline was contributed by households or individuals who experienced loss or reduction of income, particularly those with the status of employee, selfemployed and others. Furthermore, this reduction of income was not only caused by job loss but also contributed by the reduction of working hours and increase in skill-related underemployment. So, this research outcome will benefit many parties in order to contribute with alternatives to make sure students in B40, M40, and T20 family income will upgraded their living costs through entrepreneurship.

\section{Literature Review}

Entrepreneur Intention: According to Hou et al (2019) explained through the support of several other researchers that entrepreneurial intention is the subjective thinking and mental state of entrepreneurs before they implement entrepreneurial behavior (Krueger et al. 2000). Moreover, Baron (2008) suggested that a key factor in generating entrepreneurial desire is entrepreneurial passion which can stimulate the internal motivation of entrepreneurial individuals (Vallerand et al., 2010). Thus, when the entrepreneurial spirit is stimulated, emotional expression further strengthens the stimulus. Individuals 'perceptions of entrepreneurship will be enhanced as will the possibility of translating ideas into action when there have a high interest in the field of entrepreneurship.

B40, M40 and T20: From Syed A. Malika \& Abdul Rahman Ayop (2020) dinyatakan pelbagai inisiatif telah direncanakan dan dilaksanakan oleh Kerajaan Malaysia untuk meningkatkan pendapatan isi rumah $40 \%$ yang lebih rendah yang dikenali sebagai "B40". Seperti yang diklasifikasikan oleh Jabatan Statistik Malaysia (DOSM, 2019) B40, M40, and T20 refer to the household income classification in Malaysia where as B40 represents the Bottom $40 \%$ (lowerincome group and household income is below RM4,850 per month), M40 represents the middle 40\% (Middle-income group and household income between RM4,851 per to RM10,970 per month) and T20 represents the top 20\% (Upper class and household income exceeds RM10,971 a month) of Malaysian household income. Competencies of entrepreneurs plays an important role in economies through the business enterprises, so they need to run the business efficiently. Additionally, organizations will always depend on entrepreneurs who are multitasks and efficient functioning. Competencies in this research is according to Entrepreneurial Competencies (McBer \& Company, 1985). Initiative: English Oxford dictionary stated that initiative meaning is the power or opportunity to act or take charge before others do, also an act or strategy intended to resolve a difficulty or improve a situation or a fresh approach to something. Seek for Opportunity: Cambridge Dictionary stated the meaning of seek for opportunity as an entrepreneur look on such opportunities, and an occasion or situation which makes it possible to look of. Act for Opportunity: Entrepreneurs take action on such opportunities and do something that you want to do or have to do, or the possibility of doing something. Information Seeking: Wikipedia stated the meaning of information seeking as an information seeking is the process or activity of attempting to obtain 
information in both human and technological contexts. Concern for High Quality of Work: Refers to the favorable or unfavorable of a job environment for the people working in an organization. Commitment to Work Contract: Answer.com stated that the meaning is an entrepreneur always delivers his promise promptly and he values his reputation. Efficiency Orientation: Course hero stated the meaning as a successful entrepreneur always finds ways to do things faster or with fewer resources or at a lower cost. Systematic Planning: Wikipedia stated the meaning for systematic planning as a systematic planning is a planning process that is based on the scientific method and includes concepts such as objectivity of approach and acceptability of results. Problem Solving: English Oxford stated the meaning for problem solving is to engage in the actions or thoughts necessary to discover solutions to problems. Self Confidence: Referring a person who has confidence in himself or herself and in his or her own abilities. Assertiveness: Refer to confident in style or behavior where they always confront problems and issues with others directly (Fajar, 2013).

\section{Methodology}

This is a quantitative comparative study with the title 'Factors That Influence Entrepreneur Intention Between B40 And M40. Case Study, among Students At Higher Education Institutions (HEls) in Melaka.' The population for this research are from students in HEls (Public and Private HEls) which came from B40, M40 and T20 family background in Melaka. This non probability sampling method are done through convenience sampling techniques. $A$ total of 475 respondents are our sampling size for this research. Data collection method is by using survey through structured questionnairre and distributed to respondents via Google Form. This data analysis for this research are descriptive, correlation and regression backward analysis (hypothesis testing).

\section{Findings}

Reliability Test

This research Cronbach's Alpha is 0.962 means that this research instrument and questionnaire arrangement have reliability and valid at excellent level.

\section{Descriptive Analysis}

This research respondents' profile participated by Diploma Programme 414 (87.12\%) respondents and Degree Programme 61 (12.8\%) respondents. For gender analysis, shown that $365(76.8 \%)$ female and 110 (23.2\%) male. Other than that, this data analysis found that 351 (73.9\%) respondents are from public higher institutions and 124 ( $26.1 \%)$ are from private higher institution in Melaka. Most of the respondents are from age above 19 years to below 20 years $193(40.6 \%)$ respondents, above 18 years to below 19 years 181 (38.1\%) respondents, above 21 years $53(11.2 \%)$ respondents, above 20 years to below 21 years 44 (9.3\%) respondents and 18 years below $1(0.2 \%)$ respondent. For family member information, the highest are from family members four siblings 126 (26.5\%), three siblings 120 (25.3\%), five siblings and two siblings are $66(13.9 \%)$, seven siblings $20(4.2 \%)$, the only child in the family $19(4.0 \%)$ and more than 7 siblings are 22 (4.6\%). When we look at the family income, $316(66.50 \%)$ are from B40, 130 (27.4\%) are from M40 and 29 (6.1\%) are from T20.

\section{Level of Entrepreneur Intention (Objective 1)}

Level of Entrepreneur Intention for B40: A total 316 respondents are from B40 family income. The level of entrepreneur intention for B40 are stated as $144(45.6 \%)$ respondents said 
somewhat, $129(40.8 \%)$ said well and very well, $41(13 \%)$ said very little and $2(0.6 \%)$ said not at all. The result also identified the means for this level of entrepreneur intention for B40 is at somewhat level.

Level of Entrepreneur Intention for M40/T20: A total 159 respondents are from M40/T20 family income. The level of entrepreneur intention for M40/T20 are stated as 144 (45.6\%) respondents said somewhat, $60(37.7 \%)$ said well and very well, $27(17 \%)$ said very little and $1(0.6 \%)$ said not at all. The result also identified the means for this level of entrepreneur intention for M40/T20 is also at somewhat level.

The Relationship between All Factors with Entrepreneur Intention (Objective 2)

Hypothesis Testing analysis shown that this research with 10 independent variables (Innitiative, Seeks on Opprtunities, Act on Opportunities, Information Seeking, Concern for Hight Quality of Work, Comitment to Work Contract, Efficiency Orientation, Systemmatic Planning, Problem Solving, Self Confidence, and Assertiveness) are all rejected $\mathrm{H}$ null and accepted $\mathrm{H}$ alternative. (Refer Table 1)

Table 1: Correlation Coefficient

\begin{tabular}{|l|c|c|}
\hline & Pearson Correlation & Sig. (2-tailed) \\
\hline Innitiative & $.467^{* *}$ & .000 \\
\hline Seeks on Opprtunities & $.461^{* *}$ & .000 \\
\hline Act on Opportunities & $.423^{* *}$ & .000 \\
\hline Information Seeking & $.509^{* *}$ & .000 \\
\hline Concern for Hight Quality of Work & $.449^{* *}$ & .000 \\
\hline Comitment to Work Contract & $.386^{* *}$ & .000 \\
\hline Efficiency Orientation & $.384^{* *}$ & .000 \\
\hline Systemmatic Planning & $.399^{* *}$ & .000 \\
\hline Problem Solving & $.390^{* *}$ & .000 \\
\hline Self Confidence & $.438^{* *}$ & .000 \\
\hline Assertiveness & $.232^{* *}$ & .000 \\
\hline
\end{tabular}

**. Correlation is significant at the 0.01 level (2-tailed).

The Most Dominant Factor toward Entrepreneur Intention (Objective 3)

For B40, the results for the most dominant factor toward Entrepreneur Intention are Initiative, Seek on Opportunities, Information seeking and Self Confidence. (Refer Table 2) 


\begin{tabular}{|l|c|c|c|c|c|}
\hline & \multicolumn{2}{|c|}{$\begin{array}{c}\text { Unstandardized } \\
\text { Coefficients }\end{array}$} & $\begin{array}{c}\text { Standardized } \\
\text { Coefficients }\end{array}$ & \multirow{2}{*}{ t } & Sig. \\
\cline { 2 - 4 } & $\mathrm{B}$ & Std. Error & Beta & $\mathrm{t}$ & \\
\hline (Constant) & .423 & .217 & & 1.950 & .052 \\
\hline Initiative & .220 & .052 & .227 & 4.246 & .000 \\
\hline Seeks on Opportunities & .162 & .057 & .165 & 2.826 & .005 \\
\hline Information Seeking & .236 & .067 & .217 & 3.532 & .000 \\
\hline Self Confidence & .177 & .058 & .166 & 3.050 & .002 \\
\hline
\end{tabular}

Table 2 : Regression Backward for B40

a. Dependent Variable: Entrepreneur Intention

For M40/T20, the results for the most dominant factor toward Entrepreneur Intention are Seek on Opportunities and Act on Opportunities (Refer Table 3)

Table 3 : Regression Backward for M40/T20

\begin{tabular}{|l|c|c|c|c|c|}
\hline & \multicolumn{2}{|l|}{$\begin{array}{l}\text { Unstandardized } \\
\text { Coefficients }\end{array}$} & \multicolumn{2}{l|}{$\begin{array}{l}\text { Standardized } \\
\text { Coefficients }\end{array}$} & \\
\cline { 2 - 5 } & $\mathrm{B}$ & Std. Error & Beta & $\mathrm{t}$ & Sig. \\
\hline (Constant) & .439 & .374 & & 1.174 & .242 \\
\hline Seeks on Opportunities & .329 & .093 & .285 & 3.534 & .001 \\
\hline Act on Opportunities & .329 & .107 & .249 & 3.079 & .002 \\
\hline Assertiveness & .131 & .074 & .132 & 1.770 & .079 \\
\hline
\end{tabular}

a. Dependent Variable: Entrepreneur Intention

\section{Discussions and Recommendations}

\section{Discussions}

This research focused on comparative study about factors toward Entrepreneur Intention between B40 and M40/T20 among HEls students. Based on Table 4, shown the comparative level of all factors that influence entrepreneur intention between B40 and M40/T20. The results stated are all according to the means value. The scale for the means are listed as scale 1 ( not at all), scale 2 (very little), scale 3 (somewhat), scale 4 (well) and scale 5 (very well). The researcher concluded that the means for Initiative, Seek on Opportunities, Act on Opportunities, Concern for High Quality of Work, Efficiency Orientation, Systematic Planning, Self Confidence and Assertiveness for B40 are less than M40/T20. But for Information Seeking, Commitment to Work Contract and Problem Solving B40 are more than the level of means M40/T20. 
Table 4: Comparative Level of All Factors that influence Entrepreneur Intention (mean)

\begin{tabular}{|l|c|c|c|}
\hline Element & B40 & remark & M40/T20 \\
\hline Initiative & 3.6456 & Less than & 3.6604 \\
\hline Seek on Opportunities & 3.7816 & Less than & 3.8428 \\
\hline Act on Opportunities & 3.5728 & Less than & 3.6164 \\
\hline Information Seeking & 3.6361 & More than & 3.6226 \\
\hline Concern for High Quality of Work & 3.7278 & Less than & 3.7358 \\
\hline Commitment to Work Contract & 3.9778 & More than & 3.9686 \\
\hline Efficiency Orientation & 3.5222 & Less than & 3.5535 \\
\hline Systematic Planning & 3.5570 & Less than & 3.6289 \\
\hline Problem Solving & 3.5823 & More than & 3.5786 \\
\hline Self Confidence & 3.3513 & Less than & 3.3522 \\
\hline Assertiveness & 3.1930 & Less than & 3.1950 \\
\hline
\end{tabular}

In addition, this research shown the comparison ranking for all Factor toward Entrepreneur Intention between B40 and M40/T20. For B40 ranking factors toward toward Entrepreneur Intention are (1) Commitment to Work Contract, (2) Seek on Opportunities, (3) Concern for High Quality of Work, (4) Initiative, (5) Information Seeking, (6) Problem Solving, (7) Act on Opportunities, (8) Systematic Planning, (9) Self Confidence, (10) Efficiency Orientation and (11) Assertiveness.

Instead, for M40/T20 ranking factors toward toward Entrepreneur Intention are (1) Commitment to Work Contract, (2) Seek on Opportunities, (3) Concern for High Quality of Work, (4) Initiative, (5) Information Seeking, (6) Systematic Planning, (7) Act on Opportunities, (8) Problem Solving, (9) Efficiency Orientation, (10) Self Confidence and (11) Assertiveness.

\section{Recommendations}

The comparison stated the different rank for four factors which are Efficiency Orientation, Systematic Planning, Problem Solving and Self Confidence. Therefore, future research are needed in order to explore more about these four factors in the future. Also, other researchers can extend research from the perspective of students to the perspective of the community that can provide a clear and broader picture of entrepreneurial intentions among Malaysians. The independent variables can be added comprehensively and studied in more depth to obtain the accuracy of the findings of the new study which is certainly capable of providing improvements in national entrepreneurship policy.

\section{Conclusion}

This research comparison study are needed in order to identify entrepreneurship intention among students with different family income such are B40, M40 and T20. As we knew that, the impact of the Covid-19 pandemic may be temporary as the economy is expected to improve and recover as the spread of the pandemic can be contained. But still it is found that the role of the federal and state governments as well as other relevant parties is pertinent in cushioning the impact of the pandemic as well as towards reviving the household income and the country's economy. 


\section{Acknowledgement}

This research merely is not under specific grant from any funding agency in the public, commercial or not for profit sectors.

\section{Corresponding Author}

Norazman Harun

Faculty of Business and Management, UiTM Melaka Branch, Malaysia

Email: norazman@uitm.edu.my

\section{References}

Acs, Z. J., Audretsch, D. B., Braunerhjelm, P., \& Carlsson, B. (2005). Growth and Entrepreneurship: An Empirical Assessment.

Awani, A. (2021). Covid-19 pandemic has significant impact on household income, study reveals. Retrieved from website, https://www.astroawani.com/berita-malaysia/ covid19-pandemic-has-significant-impact-household-income-study-reveals-312626

Reynaldo, L., \& Panabang, M. B. (2014). An Analysis of Entrepreneurial Skills and Competencies of Students: The Case of a Philippine University. Journal of Global Business and Trade, Vol.10, No.1, pp. 37-51, May 2014, Available at SSRN: https://ssrn.com/abstract=2999231

Bird, J. B. (1995). Entreprenuerial Behaviour. London: Scott, Foresman \& Company.

Baron, R. A. (2008). The role of affffect in the entrepreneurial process. Acad. Manag. Rev. 33, 328-340. doi: 10.5465/amr.2008.31193166

Chen, C., Greene, P., \& Crick, A. (1998). Does entrepreneurial self-effiffifficacy distinguish entrepreneurs from managers? J. Bus. Ventur. 13, 295-316. doi: 10.1016/s08839026(97)00029-3.

Dosm. (2019). Report of Household Income and Basic Amenities Survey Department of Statistics of Malaysia. Retrieved from, https://www.dosm.gov.my/ v1/index.php?r=column/pdfPrev\&id =RUZ5REwveU1 ra1hGL21JWVIPRmU2Zz\%2009.

Department of Statistics of Malaysia (DOSM). (2021). Graduates Statistics 2021. Retrieved from website, https://www.dosm.gov.my/v1/index.php?r=column/cthemeByCat\&cat=476\&bul_ id=U1/tVWpwNXRNRUR2NIhRSHZmenRMUT09\&menu_id=Tm8zcnRjdVRNWWIpWjRlb mtlaDk1UT09

Fajar. (2013). Fundamentals of entrepreneurship, chapter 1-Theory of entrepreneurship. Oxford: Oxford sdn.bhd.

Guerrero, M., Rialp, J., \& Urbano, D. (2008). The impact of desirability and feasibility on entrepreneurial intentions: A structural equation model. The International Entrepreneurship and Management Journal, 4(1), 35-50.

Hou, F., Su, Y., Lu, M., \& Qi, M. (2019). Model of the Entrepreneurial Intention of University Students in the Pearl River Delta of China. Front. Psychol. 10:916. doi: 10.3389/fpsyg.2019.00916.

Kolvereid, L., \& Moen, O. (1997). Entrepreneurship among business graduates: does a major in entrepreneurship make a difffference. J. Eur. Ind. Train. 21, 154-157.

Krueger, N. F., Reilly, M. D., \& Carsrud, A. L. (2000). Competing models of entrepreneurial intentions. J. Bus. Ventur. 15, 411-432. doi: 10.1016/s0883-9026(98)00033-0. 
McBer \& Company. (1985). Test for personal entrepreneurial competencies. Special workshop on personal entrepreneurial competencies funded by USAID in Oxford, United Kingdom.

Rideout, E. C., \& Gray, D. (2013). Does entrepreneurship education really work? A review and methodological critique of the empirical literature on the effffects of university-based entrepreneurship education. J. Small Bus. Manag. 3, 329-351. doi: 10.1111/jsbm.12021.

Sharififi-Tehrani, M., Verbič, M., \& Chung, J. Y. (2013). An analysis of adopting dual pricing for museums: The case of the national museum of Iran. Annals of Tourism Research, 43, 58-80.

Syed, A. M., \& Abdul Rahman, A. (2020). Solar energy technology: Knowledge, awareness, and acceptance of B40 households in one district of Malaysia towards government initiatives. Technology in Society. Volume 63, November 2020, 101416. Retrieved from; https://doi.org/10.1016/j.techsoc.2020.101416.

Vallerand, R. J., Paquet, Y., \& Philippe, F. L. (2010). On the role of passion for work in burnout: a process model. J. Pers. 78, 289-312. doi: 10.1111/j.1467-6494.2009.00616.x. 